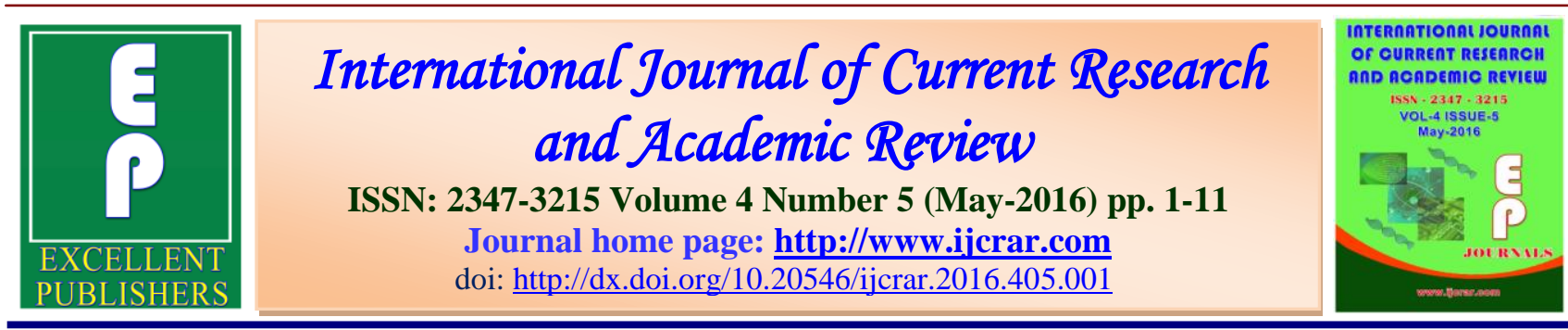

\title{
Proximate Composition, Protein Digestibility, Starch Digestibility, Physical Properties and Sensory Evaluation of Decorticated Sorghum and Maize Biscuits Supplemented with Chickpea Flour
}

\author{
Mohammed Abdel Rahman Hussain Ahmed ${ }^{1 *}$, Abdelmoneim Ibrahim Mustafa ${ }^{2}$, \\ Hayat Abdel Rahman hussan ${ }^{3}$ and Ahmed Elawad Elfaki ${ }^{4}$ \\ ${ }^{1}$ Sudan University of science and technology, Sudan \\ ${ }^{2}$ University of Khartoum, Faculty of Agric., Sudan \\ ${ }^{3}$ Food Research Centre, Khartoum North-Sudan \\ ${ }^{4}$ University of Sudan Faculty of Agric. Studies, Sudan \\ *Corresponding author
}

\section{KEYWORDS}

Proximate

composition,

protein and starch

digestibility, spread

ratio of biscuits from

sorghum and maize.
A B S T R A C T

The study was conducted to utilized decorticated sorghum and maize $(90 \%$ extraction) to produce biscuits. Biscuits were formulated and developed by compositing sorghum and maize with chickpea flour at different ratio $(10,20$, and $30 \%$ level), to establish the nutritional characteristics of biscuits, proximate composition, protein and starch digestibility, physical characteristics, and sensory evaluation of biscuits. The results showed moisture, ash, and fat content ranged between 5.11 to5.58 \%, 1.52 to 1.95, and 18.68 to $22.30 \%$, respectively. Therefore, protein, fiber, carbohydrates and energy ranged from 9.90 to $15.50 \%, 1.14$ to $2.03 \%, 55.61$ to $61.29 \%$, and 455.64 to $477.14 \mathrm{kcal} / 100 \mathrm{gm}$, respectively. Protein digestibility gained from 43.51 to $60.29 \%$, starch digestibility varied from 46.81 to $60.36 \%$ and 62.65 to $67.16 \%$ for sorghum and maize, respectively. Spread ratio ranged between 7.10 to $8.21 \mathrm{~cm}$. Hence, sorghum and maize - chickpea flour composite biscuits have a considerable potential as protein-rich supplementary food to alleviate the nutritional value. Its utilization will afford the consumer to have food with high nutritional value.

\section{Introduction}

Biscuits are ready-to-eat, cheap and convenient food product that is consumed among all age groups in many countries (Hussein et al., 2006; Iwegbue, 2012). Biscuits have been reported to be rich in fat and carbohydrate; hence they can be referred to as energy giving food as well as good sources of protein and minerals (Kure et al., 1998). The main ingredient generally used for biscuit production is wheat flour with other ingredients such as margarine (Shortening), sweeteners (sugar), leavening agents, eggs, milk, salt and flavours (Hui, 1992). 
In many parts of sub-Saharan Africa and most especially Nigeria, advancing prosperity and urbanization coupled with tremendous increase in population in recent years have led to an increase in the consumption of wheat-based products especially biscuits and breads. However, the production of wheat in Nigeria is extremely low and far below domestic requirements. Compositing wheat flour with locally available cereals and root crops has been reported to be desirable (Oyarekua et al., 2009). It also encourages the agricultural sector and reduces wheat imports in many developing countries. Considerable efforts have been focused on the use of composite flour for bread and baked products in many wheat importing countries within the last two and half decades (Mohammed et al., 2011) Sorghum is one of the crops grown in many African countries primarily as food crop with less than $5 \%$ of the annual production commercially processed by the industry (Bohoua et al., 2007; Cheng et al., 2009; Rohrbach et al., 2001; Nidaye et al., 2008). Sorghum grain ranks third among the domesticated cereals for human consumption and is a staple food in many African countries, India and China (Elkhalifa et al., 2002; Awadalkareem et al., 2008; Atwater et al., 1902).

\section{Materials and Methods}

\section{Samples Preparation}

Sorghum, maize and chickpea samples were cleaned from dust, husk, and other impurities, then sorghum and maize decorticated to $90 \%$, then all samples milled using laboratory Miller Type 120, No. 69444 Helsinki-Stockholm-Sweden into fine powder.

\section{Chemical Composition}

Moisture, ash, crude protein and fat contents were determined for sorghum, maize - chickpea supplemented products according to (AOAC, 2000) method. Fiber content was carried out on the samples according to (A. A. C. C., 2000) methods.

The carbohydrates were calculated by difference. The sum of moisture, fat, protein and ash contents were subtracted from 100 as it was described by (Vatsala, 1991). The energy values of the biscuits were calculated for protein, fat and carbohydrates based on Atwater factors.

Fat factor $=9.0(\mathrm{kcal} / \mathrm{g})$.

Protein factor $=4.0(\mathrm{kcal} / \mathrm{g})$.

$\mathrm{CHO}$ factor $=4.0(\mathrm{kcal} / \mathrm{g})$.

$1 \mathrm{kcal}=4.184(\mathrm{kj})$.

\section{In Vitro protein Digestibility (\%)}

In vitro protein digestibility of sample was carried out using enzymatic method of (22). Samples containing $100 \mathrm{mg}$ protein were treated with $12.5 \mathrm{mg}$ of pepsin in $50 \mathrm{ml}$ of $0.1 \mathrm{~N} \mathrm{HCl}$ at $37^{\circ} \mathrm{C}$ for 3 hours. After neutralization with $0.5 \mathrm{~N} \mathrm{NaOH}, 6 \mathrm{mg}$ of pancreatin dissolved in $25 \mathrm{ml}$ of phosphate buffer ( $\mathrm{pH}$ 8.0) was added and digestion continued for 24 hour at $37^{\circ} \mathrm{C}$. The volume was made to $100 \mathrm{ml}$ and $50 \mathrm{ml}$ aliquot was treated with 10 per cent TCA, left overnight to precipitate the proteins. The suspensions were centrifuged at $4000 \mathrm{rpm}$. The undigested material was subjected to protein assay by micro kjeldahl method. Protein digestibility was calculated by difference.

\section{In Vitro Starch Digestibility}

In vitro starch digestibility was carried out using the method, described by (Mouliswar et al., 1993). The slurry of sample (2\%) was cooked on a boiling water bath for 15 minutes. To a slurry sample of $50 \mathrm{ml}, 30 \mathrm{ml}$ of $0.2 \mathrm{M}$ glycine-HCl buffer (pH 2.0) containing $10 \mathrm{mg}$ of pepsin was added. It 
was incubated at $37^{\circ} \mathrm{C}$ for 2 hours and neutralized with $0.2 \mathrm{~N} \mathrm{NaOH}$ and the volume was made to $100 \mathrm{ml}$. To an aliquot of $10 \mathrm{ml}$ of this sample $5 \mathrm{ml}$ of $0.5 \mathrm{M}$ phosphate buffer containing $15 \mathrm{mg}$ of pancreatin and $15 \mathrm{mg}$ amyloglucosidase was added and incubated for 2 hours at $37^{\circ} \mathrm{C}$. The reaction was stopped at desired intervals (3 hours) by heating the samples for 5 minutes in boiling water bath. Aliquots of $0.5 \mathrm{ml}$ of these samples were mixed with 2 $\mathrm{ml}$ of dinitrosalicylicacid reagent for determining reducing sugars. Glucose was used as a standard, while starch equivalent was calculated using the conversion factor of 0.9 .

\section{Processing of Biscuit Samples}

Biscuits were prepared according to (Vatsala et al., 1991) method. Control sample of decorticated sorghum flour ( $90 \%$ extraction) and decorticated maize flour $(90 \%$ extraction) (Non wheat flour) had been blended with chickpea flour substituting in ratio $0,10,20$ and $30 \%$. The formula used in biscuit processing were as follows:

Ingredient Quantity (gm)

$\begin{array}{lc}\text { Biscuit flour } & 100 \\ \text { Sugar powde } \mathrm{r} & 30 \\ \text { Shortening } & 30 \\ \text { Skim milk powder } & 2 \\ \text { Sodium chloride } & 1 \\ \text { Sodium bicarbonate } & 0.4 \\ \text { Ammonium bicarbonate } & 1.5 \\ \text { Glucose } & 2 \\ \text { Water } & 15 \mathrm{ml}\end{array}$

The ingredients were weighed for $400 \mathrm{gm}$ of flour. Sugar powder, shortening, skim milk powder, and glucose were creamed in Hobart N-50 mixer with a flat beater for 3 min. at $61 \mathrm{rpm}$. Salt, ammonium bicarbonate and sodium bicarbonate were dissolved separately in part of required water added to the cream. Mixing was continued for $8 \mathrm{~min}$. at $125 \mathrm{rpm}$ to obtain homogenous cream. Finally, flour was added and mixed for $3 \mathrm{~min}$. at $60 \mathrm{rpm}$, and then the dough was sheeted to a thinness of $3.5 \mathrm{~mm}$ with the help of an aluminum plate form and a frame. The piece dough was transferred to an aluminum tray. The biscuits were baked in electronic oven maintained at $205{ }^{\circ} \mathrm{C}$ for 8.5 min., the baked units were cooled, packed in polyethylene bags and stored for further analysis.

\section{Biscuit Spread ratio}

Biscuit were evaluated for the spread ratio according to the following equation:

Spread ratio $=$ Width of the biscuit

Thickness of the biscuit

\section{Sensory Evaluation of Biscuits}

Evaluation of biscuits made from sorghum and maize flours with and without chickpea flour were carried out. Fifteen panelist assessors provided coded samples and asked to evaluate the general appearance, color, after taste, texture, and overall quality of the biscuits according to the scoring (Hedonic) scale of 5 point. Describe by (Ihekoronye et al., 1985). A key table was given to the panelists guided them to score according to it.

\section{Statistical Analysis}

The analysis of variance was performed to examine the significant effect in all parameters measured. Duncan Multiple Range Test was used to separate the means.

\section{Results and Discussion}

\section{Proximate Composition}

Table (1) shows proximate composition of biscuits prepared from decorticated sorghum 
and maize supplemented with chickpea flour (10, 20 and 30\% level). Data are expressed on dry matter bases (per 100gm materials). The moisture content of biscuits was assessed between 5.58 and $5.11 \%$. These values are agreement with Omoba and Omogbemile (Omoba et al., 2013). Moisture content of sorghum biscuit enriched with defatted soy flour ranged from $3.2-6.1 \%$. These values are comparable to values (5$10 \%$ ) set by the Protein Advisory Group. The lower the moisture contents ofa product, the better the shelf stability of such product (Sanni et al., 2008). Hence, low moisture ensures higher shelf stability in dried products.

However, low residual moisture content in confectionaries is advantageous; resulting in a reduction in microbial proliferation and prolonged storage life if stored inside appropriate packaging materials under good environmental condition. The ash content (table1) of the biscuits ranged from 1.52 $1.95 \%$, respectively. These results significantly $(\mathrm{P} \leq 0.05)$ lower than the range of $2.3-3.5 \%$ stated by (Omoba et al., 2013). Lower ash content obtained resulted from sorghum and maize had been decorticated before utilizing. The fat content of biscuits ranged from $18.68-22.30 \%$. These values are considered higher than the range of 12.0 - $18.1 \%$ stated by (Omoba et al., 2013). The fat content plays a role in determine the shelf life of the food. A high amount of fat could accelerate spoilage by promoting rancidity which could lead to the production of off flavours and odours. The protein content of biscuits is given in table (1) results, however, showed values ranged from $9.9-15.5 \%$, highest value observed in maize biscuit with 30\% chickpea flour (M3), and the lowest value gained by sorghum biscuit (S) (without chickpea flour). Protein content significantly increased $(\mathrm{P} \leq 0.05)$ gradually after chickpea inclusion in sorghum and maize flour with 10, 20, and $30 \%$ level. The fiber content analysis of the biscuits table (1) showed the values obtained ranged between $1.14-2.03 \%$, high fiber values were observed in maize biscuit with $30 \%$ chickpea flour (M3) and sorghum biscuit with 30\%chickpea flour (S3), respectively. These values favorably agree with the recommended value of $2.0-3.8 \%$ by (Omoba et al., 2013). Carbohydrate content of biscuit viewed in (table1) ranged from $55.61-61.29 \%$. The results appeared carbohydrate decreased significantly $(\mathrm{P} \leq 0.05)$ in sorghum and maize biscuits. The calculated energy values of biscuits ranged from 455.64 - $477.14 \mathrm{kcal} / 100 \mathrm{gm}$. The energy density of biscuits in the study was enhanced by inclusion of fat in the formulation. The results obtained of energy meet the recommended minimum value of $1674 \mathrm{kj} / 100 \mathrm{gm}$ for supplementary food for young children. High dietary energy is important for sparing protein for body building and repairing body tissues avoiding diversion to provide energy.

\section{In Vitro Protein Digestibility}

In vitro protein digestibility of biscuits prepared from sorghum and maize supplementing with chickpea flour $(10,20$, and $30 \%$ level). Table (2) showed the in vitro protein digestibility ranged from 43.51 - $60.29 \%$. Lowest value obtained by sorghum biscuit without chickpea flour (S), maize biscuit with $30 \%$ chickpea flour gained the highest value. These results showed in vitro protein digestibility increase significantly $(\mathrm{P} \leq 0.05)$ with increasing the level of chickpea flour in sorghum and maize biscuit, respectively. Generally, protein digestibility values of sorghum biscuits seemed to be low. These results obtained agree with who reported effect of cooking on protein digestibility at the three level of organization, cooking caused a 
significant reduction in protein digestibility for both sorghum varieties (high and low tannins).Maize biscuits in vitro protein digestibility values increased significantly $(\mathrm{P} \leq 0.05)$ with increasing the level of chickpea flour from $46.59-60.20 \%$, respectively. The relatively low protein digestibility maybe attributed to the influence of anti-nutrients such as enzyme inhibitors, tannins, and phytates which inhibits protein digestion and also due to presence of protein structures that resist digestion (Mrooj, 2011).

\section{Starch Digestibility}

Table (2) showed the in vitro starch digestibility of sorghum biscuits which was blending with chickpea flour (10, 20, and $30 \%$ level). Starch digestibility ranged from $46.81-60.36 \%$, respectively. The results obtained shows starch digestibility significantly increase $(\mathrm{P} \leq 0.05) \quad$ with increasing the level of chickpea flour. Most starch related foods are cooked before consumption and consequent starch gelatinization and retro gradation play important roles in the quality and digestibility of the many resultant food products (Hu et al., 2004).

On the other hand, starch digestibility of maize blending with chickpea flour $(10,20$, and $30 \%$ level) presented in table (2), the results showed starch digestibility increased significantly $(\mathrm{P} \leq 0.05)$ from 62.65 $67.16 \%$ with the addition of chickpea flour. These result is high than (Hernández-Salazar et al., 2006) stated that commercial maize bean tortilla digestible starch content of $60.3 \mathrm{gm} / 100 \mathrm{gm}$ was reported, but the ratio is not declare.

\section{Physical Characteristics of Biscuits}

Table (3) shows the physical properties of sorghum and maize biscuits supplemented with chickpea flour(10, 20, and 30\% level). The results observed appeared a significant difference $(\mathrm{P} \leq 0.05)$ in diameter, thickness, and spread ratio of sorghum and maize biscuits supplemented with chickpea flour.

The diameter values ranged from $5.24-$ $5.50 \mathrm{~cm}$.the least diameter observed in $(\mathrm{S} 1)$ sorghum biscuit incorporated with $10 \%$ chickpea flour inclusion. Whereas, the high diameter obtained by (M2) maize biscuit supplemented with 20\%chickpea flour. Thickness of biscuits made from sorghum and maize incorporated with chickpea flour (10, 20, and 30\% level) varied from $0.065-0.75 \mathrm{~cm}$.

Spread ratio of the biscuits ranged from 7.10 to $8.21 \mathrm{~cm}$. Biscuit having higher spread ratio are considered the most desirable. M2 is therefore considered as the most desirable. The spread ratio increased significantly $(\mathrm{P} \leq 0.05)$ with increasing the chickpea flour in biscuits of both sorghum and maize. Spread ratio could have been affected by the competition of ingredients for the available water and other functional properties of proteins and fat. Invariably, this might affect the texture and eating quality of the biscuits. There is a relationship between the spread ability, thickness of differently biscuits, the thinner the biscuit the lesser its ability to with stand stress/load.

\section{Sensory Evaluation of Biscuits}

The organoleptic properties of the biscuit including colour, odour, taste, texture, and general acceptability were assessed by a 10member panelists who are familiar with the product, nine point hedonic scale with 1 representing the least score (poor) and 9 the highest score (excellent) analysis of variance (ANOVA) was performed on the data to determine differences, while the Duncan multiple range test was used to separate means where significant difference existed. 
Int.J.Curr.Res.Aca.Rev.2016; 4(5): 1-11

Table.1 Proximate Composition of Biscuit Samples

\begin{tabular}{|c|c|c|c|c|c|c|c|}
\hline Samples & Moisture content (\%) & Ash content (\%) & Fat content $(\%)$ & Crude protein (\%) & Crude fibre (\%) & Carbohydrate (\%) & Energy (kcal)/100gm \\
\hline $\mathbf{S}$ & $\begin{array}{l}5.36^{\mathrm{c}} \\
\pm 0.02\end{array}$ & $\begin{array}{l}1.64^{\mathrm{d}} \\
\pm 0.03\end{array}$ & $\begin{array}{l}20.60^{\mathrm{d}} \\
\pm 0.01\end{array}$ & $\begin{array}{l}9.90^{\mathrm{g}} \\
\pm 0.10\end{array}$ & $\begin{array}{l}1.20^{\mathrm{e}} \\
\pm 0.01\end{array}$ & $\begin{array}{l}61.29^{\mathrm{a}} \\
\pm 0.07\end{array}$ & $\begin{array}{l}470.32^{\mathrm{c}} \\
\pm 0.35\end{array}$ \\
\hline$\overline{S_{1}}$ & $\begin{array}{l}5.52^{\mathrm{ab}} \\
\pm 0.02\end{array}$ & $\begin{array}{l}1.75^{\mathrm{c}} \\
\pm 0.02 \\
\end{array}$ & $\begin{array}{l}21.93^{\mathrm{b}} \\
\pm 0.01\end{array}$ & $\begin{array}{l}11.43^{\mathrm{e}} \\
\pm 0.16\end{array}$ & $\begin{array}{l}1.43^{\mathrm{d}} \\
\pm 0.05\end{array}$ & $\begin{array}{l}57.94^{\mathrm{c}} \\
\pm 0.18\end{array}$ & $\begin{array}{l}474.81^{\mathrm{b}} \\
\pm 0.35\end{array}$ \\
\hline$\overline{\mathbf{S}_{2}}$ & $\begin{array}{l}3.57^{\mathrm{a}} \\
\pm 0.01 \\
\end{array}$ & $\begin{array}{l}1.81^{\mathrm{b}} \\
\pm 0.01 \\
\end{array}$ & $\begin{array}{l}21.44^{\mathrm{c}} \\
\pm 0.01 \\
\end{array}$ & $\begin{array}{l}12.79^{\mathrm{d}} \\
\pm 0.19 \\
\end{array}$ & $\begin{array}{l}1.78^{\mathrm{c}} \\
\pm 0.08 \\
\end{array}$ & $\begin{array}{l}56.60^{\mathrm{e}} \\
\pm 0.26 \\
\end{array}$ & $\begin{array}{l}470.55^{\mathrm{c}} \\
\pm 0.22 \\
\end{array}$ \\
\hline$\overline{S_{3}}$ & $\begin{array}{l}5.29^{\mathrm{c}} \\
\pm 0.02\end{array}$ & $\begin{array}{l}1.85^{\mathrm{b}} \\
\pm 0.05\end{array}$ & $\begin{array}{l}21.40^{\mathrm{c}} \\
\pm 0.43\end{array}$ & $\begin{array}{l}13.92^{\mathrm{c}} \\
\pm 0.05\end{array}$ & $\begin{array}{l}1.92^{\mathrm{b}} \\
\pm 0.06\end{array}$ & $\begin{array}{l}55.61^{\mathrm{f}} \\
\pm 0.34\end{array}$ & $\begin{array}{l}470.73^{\mathrm{c}} \\
\pm 2.33\end{array}$ \\
\hline $\bar{M}$ & $\begin{array}{l}5.30^{\mathrm{c}} \\
\pm 0.01 \\
\end{array}$ & $\begin{array}{l}1.52^{\mathrm{e}} \\
\pm 0.02 \\
\end{array}$ & $\begin{array}{l}21.46^{\mathrm{c}} \\
\pm 0.01 \\
\end{array}$ & $\begin{array}{l}11.14^{\mathrm{f}} \\
\pm 0.28 \\
\end{array}$ & $\begin{array}{l}1.14^{\mathrm{e}} \\
\pm 0.05 \\
\end{array}$ & $\begin{array}{l}59.44^{b} \\
\pm 0.26 \\
\end{array}$ & $\begin{array}{l}475.46^{\mathrm{b}} \\
\pm 0.29 \\
\end{array}$ \\
\hline $\mathbf{M}_{1}$ & $\begin{array}{l}5.58^{\mathrm{a}} \\
\pm 0.01\end{array}$ & $\begin{array}{l}1.62^{\mathrm{d}} \\
\pm 0.04\end{array}$ & $\begin{array}{l}22.30^{\mathrm{a}} \\
\pm 0.02\end{array}$ & $\begin{array}{l}12.86^{\mathrm{d}} \\
\pm 0.06\end{array}$ & $\begin{array}{l}1.39^{\mathrm{d}} \\
\pm 0.00\end{array}$ & $\begin{array}{l}56.25^{\mathrm{e}} \\
\pm 0.03\end{array}$ & $\begin{array}{l}477.14^{\mathrm{a}} \\
\pm 0.26\end{array}$ \\
\hline $\mathbf{M}_{2}$ & $\begin{array}{l}5.11^{\mathrm{d}} \\
\pm 0.07\end{array}$ & $\begin{array}{l}1.73^{\mathrm{c}} \\
\pm 0.03 \\
\end{array}$ & $\begin{array}{l}19.40^{\mathrm{e}} \\
\pm 0.01 \\
\end{array}$ & $\begin{array}{l}14.40^{\mathrm{b}} \\
\pm 0.01 \\
\end{array}$ & $\begin{array}{l}1.78^{\mathrm{c}} \\
\pm 0.06 \\
\end{array}$ & $\begin{array}{l}57.57^{\mathrm{d}} \\
\pm 0.12 \\
\end{array}$ & $\begin{array}{l}462.52^{\mathrm{d}} \\
\pm 0.45\end{array}$ \\
\hline $\mathbf{M}_{3}$ & $\begin{array}{l}5.46^{\mathrm{b}} \\
\pm 0.09\end{array}$ & $\begin{array}{l}1.95^{\mathrm{a}} \\
\pm 0.02\end{array}$ & $\begin{array}{l}18.68^{\mathrm{f}} \\
\pm 0.01\end{array}$ & $\begin{array}{l}15.50^{\mathrm{a}} \\
\pm 0.12\end{array}$ & $\begin{array}{l}2.03^{\mathrm{a}} \\
\pm 0.03\end{array}$ & $\begin{array}{l}56.37^{\mathrm{e}} \\
\pm 0.07\end{array}$ & $\begin{array}{l}455.64^{\mathrm{e}} \\
\pm 0.28\end{array}$ \\
\hline $\mathbf{L s d}_{\mathbf{0 . 0 5}}$ & $0.07741^{*}$ & $0.05474^{*}$ & $0.2625^{*}$ & $0.2508^{*}$ & $0.07741^{*}$ & $0.3374^{*}$ & $1.519^{*}$ \\
\hline $\mathrm{SE} \pm$ & 0.02582 & 0.01826 & 0.08756 & 0.08367 & 0.02582 & 0.1125 & 0.5066 \\
\hline
\end{tabular}

Values are meanSD

Mean(s) having different superscript(s) in a column are significantly different $(\mathrm{P} \leq 0.05)$ according to DMRT.

Key: $\mathbf{S}=$ Biscut made from decorticated sorghum., $\mathbf{S}_{\mathbf{1}}=$ Biscuit made from decorticated sorghum with $10 \%$ chickpea flour in the formulation., $\mathbf{S}_{\mathbf{2}}$ $=$ Biscuitmade from decorticated sorghum with $20 \%$ chickpea flour in the formulation, $\mathbf{S}_{\mathbf{3}}=$ Biscuit made from decorticated sorghum with $30 \%$ chickpea flour in the formulation., $\mathbf{M}=$ Biscuit made from decorticated maize, $\mathbf{M}_{\mathbf{1}}=$ Biscuit made from decorticated maize with $10 \%$ chickpea flour in the formulation. $\mathbf{M}_{\mathbf{2}}=$ Biscuit made from decorticated maize with $20 \%$ chickpea flour in the formulation, $\mathbf{M}_{3}=$ Biscuit made from decorticated maize with $30 \%$ chickpea flour in the formulation. 
Int.J.Curr.Res.Aca.Rev.2016; 4(5): 1-11

Table.2 Biscuits Protein and Starch Digestibility (\%)

\begin{tabular}{|c|c|c|}
\hline Sample & Protein digestibility\% & Starch digestibility\% \\
\hline $\mathbf{S}$ & $43.51^{\mathrm{h}}$ & $46.81^{\mathrm{h}}$ \\
& \pm 0.02 & \pm 0.03 \\
\hline $\mathbf{S}_{\mathbf{1}}$ & $45.49^{\mathrm{g}}$ & $48.81^{\mathrm{g}}$ \\
& \pm 0.02 & \pm 0.03 \\
\hline $\mathbf{S}_{\mathbf{2}}$ & $47.13^{\mathrm{e}}$ & $50.63^{\mathrm{f}}$ \\
& \pm 0.03 & \pm 0.03 \\
\hline $\mathbf{S}_{\mathbf{3}}$ & $58.60^{\mathrm{b}}$ & $60.36^{\mathrm{e}}$ \\
& \pm 0.03 & \pm 0.03 \\
\hline $\mathbf{M}$ & $46.59^{\mathrm{f}}$ & $62.65^{\mathrm{d}}$ \\
& \pm 0.02 & \pm 0.03 \\
\hline $\mathbf{M}_{\mathbf{1}}$ & $48.13^{\mathrm{d}}$ & $63.56^{\mathrm{c}}$ \\
& \pm 0.02 & \pm 0.21 \\
\hline $\mathbf{M}_{\mathbf{2}}$ & $50.20^{\mathrm{c}}$ & $65.30^{\mathrm{b}}$ \\
& \pm 0.02 & \pm 0.03 \\
\hline $\mathbf{M}_{\mathbf{3}}$ & $60.29^{\mathrm{a}}$ & $67.16^{\mathrm{a}}$ \\
& \pm 0.02 & \pm 0.04 \\
\hline $\mathbf{L s d}_{\mathbf{0 . 0 5}}$ & $0.0005474^{*}$ & $0.1341^{*}$ \\
\hline $\mathbf{S E}$ & 0.0001826 & 0.04472 \\
\hline
\end{tabular}

Values are meanSD

Mean(s) having different superscript(s) in a column are significantly different $(\mathrm{P} \leq 0.05)$ according to DMRT

Table.3 Spread Ratio of Biscuit

\begin{tabular}{|c|c|c|c|}
\hline Sample & Width (cm) & Thickness (cm) & Spread ratio (cm) \\
\hline $\mathbf{S}$ & $5.26^{\mathrm{f}}$ & $0.75^{\mathrm{a}}$ & $6.99^{\mathrm{c}}$ \\
& \pm 0.03 & \pm 0.02 & \pm 0.20 \\
\hline $\mathbf{S}_{\mathbf{1}}$ & $5.24^{\mathrm{h}}$ & $0.73^{\mathrm{d}}$ & $7.15^{\mathrm{c}}$ \\
& \pm 0.01 & \pm 0.01 & \pm 0.05 \\
\hline $\mathbf{S}_{\mathbf{2}}$ & $5.36^{\mathrm{b}}$ & $0.74^{\mathrm{b}}$ & $\pm .21^{\mathrm{c}}$ \\
& \pm 0.02 & \pm 0.01 & $8.16^{\mathrm{a}}$ \\
\hline $\mathbf{S}_{\mathbf{3}}$ & $5.31^{\mathrm{d}}$ & $0.65^{\mathrm{h}}$ & \pm 0.02 \\
\hline $\mathbf{M}^{\mathrm{h}}$ & \pm 0.01 & \pm 0.00 & $7.10^{\mathrm{c}}$ \\
\hline $\mathbf{M}_{\mathbf{1}}$ & $5.25^{\mathrm{g}}$ & $0.74^{\mathrm{c}}$ & \pm 0.19 \\
\hline $\mathbf{M}_{\mathbf{2}}$ & \pm 0.02 & \pm 0.02 & $7.57^{\mathrm{b}}$ \\
& $5.30^{\mathrm{e}}$ & $0.70^{\mathrm{e}}$ & 8.00 \\
\hline $\mathbf{M}_{\mathbf{3}}$ & \pm 0.00 & \pm 0.00 & \pm 0.21 \\
\hline $\mathbf{L s d}_{\mathbf{0 . 0 5}}$ & $5.50^{\mathrm{a}}$ & $0.67^{\mathrm{g}}$ & $7.80^{\mathrm{b}}$ \\
\hline $\mathbf{S E}$ & \pm 0.00 & \pm 0.02 & \pm 0.17 \\
\hline
\end{tabular}

Values are meanSD

Mean(s) having different superscript(s) in a column are significantly different $(\mathrm{P} \leq 0.05)$ according to DMRT. 
Int.J.Curr.Res.Aca.Rev.2016; 4(5): 1-11

Table.4 Sensory Evaluation of Biscuits

\begin{tabular}{|c|c|c|c|c|c|}
\hline Sample & Colour & Odour & Taste & Texture & $\begin{array}{c}\text { General } \\
\text { acceptability }\end{array}$ \\
\hline $\mathbf{S}$ & $\begin{array}{c}3.07^{\mathrm{e}} \\
( \pm 2.15) \\
\end{array}$ & $\begin{array}{c}3.60^{\mathrm{c}} \\
( \pm 2.13) \\
\end{array}$ & $\begin{array}{c}3.40^{\mathrm{c}} \\
( \pm 2.26) \\
\end{array}$ & $\begin{array}{c}4.13^{\mathrm{d}} \\
( \pm 2.13) \\
\end{array}$ & $\begin{array}{c}3.47^{\mathrm{d}} \\
( \pm 2.36)\end{array}$ \\
\hline $\mathbf{S}_{1}$ & $\begin{array}{l}4.20^{\mathrm{de}} \\
( \pm 2.18)\end{array}$ & $\begin{array}{c}3.73^{\mathrm{c}} \\
( \pm 1.83)\end{array}$ & $\begin{array}{c}3.60^{\mathrm{c}} \\
( \pm 2.03)\end{array}$ & $\begin{array}{c}4.07^{\mathrm{d}} \\
( \pm 1.83)\end{array}$ & $\begin{array}{c}3.67^{\mathrm{d}} \\
( \pm 1.84)\end{array}$ \\
\hline $\mathbf{S}_{2}$ & $\begin{array}{c}5.27^{\mathrm{cd}} \\
( \pm 2.12)\end{array}$ & $\begin{array}{c}4.33^{\mathrm{c}} \\
( \pm 1.88)\end{array}$ & $\begin{array}{c}4.47^{\mathrm{bc}} \\
( \pm 2.20)\end{array}$ & $\begin{array}{c}4.60^{\mathrm{cd}} \\
( \pm 1.80)\end{array}$ & $\begin{array}{c}4.67^{\mathrm{cd}} \\
( \pm 1.95)\end{array}$ \\
\hline $\mathbf{S}_{\mathbf{3}}$ & $\begin{array}{l}5.47^{\text {bcd }} \\
( \pm 1.30)\end{array}$ & $\begin{array}{c}4.93^{\mathrm{bc}} \\
( \pm 1.28)\end{array}$ & $\begin{array}{c}5.40^{\mathrm{ab}} \\
( \pm 1.50)\end{array}$ & $\begin{array}{l}5.20^{\text {bcd }} \\
( \pm 1.32)\end{array}$ & $\begin{array}{c}5.47^{\mathrm{bc}} \\
( \pm 1.36)\end{array}$ \\
\hline $\mathbf{M}$ & $\begin{array}{l}6.27^{\mathrm{abc}} \\
( \pm 1.91)\end{array}$ & $\begin{array}{c}6.67^{\mathrm{a}} \\
( \pm 1.63)\end{array}$ & $\begin{array}{c}6.73^{\mathrm{a}} \\
( \pm 1.53)\end{array}$ & $\begin{array}{c}6.60^{\mathrm{ab}} \\
( \pm 1.55)\end{array}$ & $\begin{array}{c}6.87^{\mathrm{a}} \\
( \pm 1.60)\end{array}$ \\
\hline $\mathbf{M}_{1}$ & $\begin{array}{r}7.33^{\mathrm{a}} \\
( \pm 1.23) \\
\end{array}$ & $\begin{array}{c}6.40^{\mathrm{a}} \\
( \pm 1.92) \\
\end{array}$ & $\begin{array}{c}6.87^{\mathrm{a}} \\
( \pm 1.55) \\
\end{array}$ & $\begin{array}{c}6.73^{\mathrm{a}} \\
( \pm 1.75) \\
\end{array}$ & $\begin{array}{c}6.93^{\mathrm{a}} \\
( \pm 1.62) \\
\end{array}$ \\
\hline $\mathbf{M}_{2}$ & $\begin{array}{l}6.60^{\mathrm{abc}} \\
( \pm 0.91)\end{array}$ & $\begin{array}{c}5.93^{\mathrm{ab}} \\
( \pm 1.79)\end{array}$ & $\begin{array}{c}6.27^{\mathrm{a}} \\
( \pm 1.53)\end{array}$ & $\begin{array}{c}6.07^{\mathrm{ab}} \\
( \pm 1.87)\end{array}$ & $\begin{array}{c}6.27^{\mathrm{ab}} \\
( \pm 1.44)\end{array}$ \\
\hline $\mathbf{M}_{3}$ & $\begin{array}{c}6.80^{\mathrm{ab}} \\
( \pm 1.61) \\
\end{array}$ & $\begin{array}{c}6.00^{\mathrm{ab}} \\
( \pm 2.04) \\
\end{array}$ & $\begin{array}{c}6.33^{\mathrm{a}} \\
( \pm 1.99) \\
\end{array}$ & $\begin{array}{l}5.87^{\mathrm{abc}} \\
( \pm 2.10) \\
\end{array}$ & $\begin{array}{r}6.53^{\mathrm{ab}} \\
( \pm 1.88) \\
\end{array}$ \\
\hline $\operatorname{Lsd}_{0.05}$ & $1.257^{*}$ & $1.323^{*}$ & $1.339^{*}$ & $1.311^{*}$ & $1.289^{*}$ \\
\hline $\mathrm{SE} \pm$ & 0.4487 & 0.4722 & 0.4778 & 0.468 & 0.46 \\
\hline
\end{tabular}

Values are mean \pm SD

Mean value(s) sharing same superscript(s) in a column are not significantly different $(\mathrm{P} \leq 0.05)$.

The scores of sensory biscuit samples made from sorghum flour and maize flour with and without addition flour of chickpea with different levels (10, 20 and 30\%). The results of colour appeared that sorghum substitution with 30\% level of chickpea flour gained 5.47 score. There also, sorghum with the addition of 10 and 20\% levels of chickpea flour gained 4.20 and 5.27 scores respectively. No significant differences were obtained. The lowest score was appeared in sorghum without chickpea added. On the other hand, results of maize flour with and without inclusion of chickpea flour gave $6.27, \quad 7.33, \quad 6.60$ and 6.80 scores respectively. No significant differences were noticed, these results were considered better than the results obtained with sorghum.

Where as, odour scores results of biscuits mentioned that odour scores of sorghum flour and its treatments levels ranged between 3.60 and 4.93 scores. Maize flour with and without chickpea flour scores ranged between 6.67 and 5.93 scores from the results no significant difference was appeared between sorghum with30\%chickpea flour and maize flour with and without chickpea flour in all levels which studied. The results were better than those obtained by sorghum flour with and without chickpea flour $(0,10$ and $20 \%$ level).

It's obviously taste scores of sorghum flour with 30\% chickpea flour and maize with and without chickpea flour 10, 20 and 30\% levels gained highest scores 5.40, 6.73, 6.87, 6.27 and 6.33 scores respectively, and no significant differences were observed. Whereas, sorghum with zero, 10 and $20 \%$ level gave the lowest scores 3.40, 3.60, and 
4.47, respectively. No significance differences were noticed.

Table (4) showed that texture scores of biscuits produced from sorghum and maize with and without incorporation of chickpea flour with 10, 20 and 30\% level. Theresults indicated that highest scores obtained were 6.60, 6.73, 6.07 and 5.87, respectively, from maize and its levels of chickpea flour.

No significant differences were noticed among maize and incorporated levels of chickpea, so, there were no significant differences between maize and sorghum in $30 \%$ level of chickpea. From results the least scores were appeared in sorghum 4.13 and 4.07 score with zero and 10\%level respectively.

The results of general acceptability scores of biscuits appeared that maize and its levels of chickpea flour gained the highest scores $6.87,6.93,6.27$ and 6.5 , respectively. No significant differences were obtained. Lowest scores were observed from sorghum with zero, 10 and $20 \%$ level of chickpea flour. The results mentioned that no significant differences were noticed between sorghum and sorghum with different levels of chickpea.

\section{Conclusion and Recommendations}

Decorticated sorghum and maize biscuits supplemented with chickpea flour at 10,20 and $30 \%$ imparts positive characteristics such as increased spread factor and crispy texture and reduced hard. Sorghum and maize biscuits, made from staples fortified with chickpea have a moderately high acceptability.

Hence, decorticated sorghum and maize chickpea flour composite biscuits have a considerable potential as protein-rich supplementary food to elevate the nutritional value. Its utilization will afford the consumer to have food with high nutritional value.

It is recommended that using the chickpea with sorghum and maize to produce biscuits for people who suffer from celiac disease as safe food.

\section{References}

A.A.C.C. 2000. Approved Methods of American Association of Cereal Chem., 10th ed., St. Paul, MN., USA.

AOAC. 2000. Official Methods of Analysis of the Association of Official Analytical Chemists, 17th ed. In: Horwitz W, editor. Washington, D.C.: Association of Official Analytical Chemists.

Awadalkareem, A.M., A.I. Mustafa, A.H. El Tinay. 2008. Protein, mineral content and amino acid profile of sorghum flour as influenced by soybean protein concentrate supplementation. Pak. J. Nutr., 7: 475-479.

Atwater, W.O., Benedict, F.G. 1902. Experiments on the metabolism of matter and energy in the human body, 1898-1900.US Office of Experiment Stations Bulletin No. 109, Government Printing Office, Washington, DC.

Bohoua, G.L., Yelakan, C.K.K. 2007. Effect of germinated sorghum flour on the performance of laying hens (Warren). Int. J. Poult. Sci., 6: 122124.

Cheng, S., Sun, Y., Halgreen, L. 2009. The relationships of sorghum kernel pericarp and testa characteristics with tannin content. Asian J. Crop Sci., 1: 1-5.

Elemo, G.N., B.O. Elemo, Okafor, J.N.C. 2011. Preparation and nutritional 
Int.J.Curr.Res.Aca.Rev.2016; 4(5): 1-11

composition of a weaning food formulated from germinated

sorghum (Sorghum bicolor) and steamed cooked cowpea (Vignaun guiculata Walp.). Am. J. Food Technol., 6: 413-421.

Elkhalifa, A.E.O., El-Tinay, A.H. 2002. Effect of cysteine on bakery products from wheat-sorghum blends. Food Chem., 77: 133-137.

Ghattas, L.A., Hanna, L.M., Tapozada, S.T., El-Shebini, S.M. $2008 . \quad$ Some complementary hypoglacemic supplements from grain legumes for the management of type 2 diabetic mellitus. J. Med. Sci., 8: 102-110.

FAO/WHO. 1994. Codex Alimentarius: Foods for Special Dietary uses (including Foods for Infants and Children). Joint FAO/WHO Food Standards Programme, Codex Alimentarious Commission, Vol 4, 2nd Ed. Food and Agri. Organization, Rome.

Hernández-Salazar, M., Agama-Acevedo, E., Sáyago-Ayerdi, S.G., Tovar, J., Bello-Pérez, L.A. 2006. Chemical composition and starch digestibility of tortillas prepared with nonconventional commercial nixtamalized maize flours. Int. J. Food Sci. Nutr., 57: 143-150.

Hu, P., Zhao, H., Duan, Z.; Zhang, L., Wu, D. 2004. Starch digestibility and the estimated glycemic score of different types of rice differing in amylose contents. J. Cereals Sci., 40(3): 231237.

Hui, Y.H. 1992. Encyclopedia of food Science and Technology. John Wiley and Sons, Inc., Canada, pp: 204-210.

Hussein, H.M., Hussein, M.M., ElDamohery, S.T. 2006. The effect of natural formulated functional biscuits on elderly bone health. $J$. Medical Sci., 6: 937-943.
Ihekoronye, A.I., Ngoddy, P.O. 1985. Integrated Food and Technology for the Tropics, Macmillan Publisher, London.

Iwegbue, C.M.A. 2012. Metal contents in some brands of biscuits consumed in southern Nigeria. Am. J. Food Technol., 7: 160-167.

Kure, O.A., E.J. Bahayo, Daniel, E.A. 1998. Studies in the proximate composition and effect of flour particle size on acceptability of biscuit produced from blends of soya beans and plantain flours. Namida Tech-scope J., 3: 17-21.

MacLean, W.C., De Romana., Placko, R.P., Graham, G.G. 1981. Protein quality and digestibility of sorghum in preschool children: Balance studies and plasma amino acids. $J$. Nutr., 111: 1928-1936.

Mepba, H.D.L., Eboh, S.U., Nwaojigwa. 2005. Chemical composition, functional and baking properties of wheat-plantain composite flours. Afr. J. Food Agric. Nutr. Dev., 7: 1-22.

Mertz, E.T., Hassen, M.M., CairnsWhittern, C., Kirleis, A.W., Tu, L., Axtell, J.D. 1984. Pepsin digestibility of proteins in sorghum and other major cereals. Proc. Natl. Acad Sci. USA, 81: 1-2.

Mohammed, M.A.E., Makki, H.M.M., Mustafa, A.E.M.I. 2011. Production of cereal-based infant food from sorghum Sorghum bicolor (L) Moench) and pigeon pea (Cajanuscajan). Pak. J. Nutr., 10: 910-913.

Mouliswar, P., Kurien, S., Daniel, V.A., Malleshi, N.G., Venkatarao, S. 1993. In vitro digestibility of protein and starch as energy food and its bulk reduction. J. Food Sci. Technol., 30: 36-39. 
Mrooj, A. 2011. Influence of processing on dietary fiber, tannin and in vitro protein digestibility of pearl millet. Food and Nutr. Sci., 2: 895-900.

Nidaye, C., Xu, S.Y., Ngom, P.M., Ndoye, A.S. 2008. Malting germination effect on rheological properties and cooking time of millet (P. typhoides) and Sorghum (S. bicolor) flours and rolled flour products (Arraw). Am. J. Food Technol., 3: 373-383.

Okoli, E.V., B.N. Okolo, Moneke, A.N., F.S. Ire. 2010. Effects of cultivar and germination time on amylolytic potential, extract yield and wort fermenting properties of malting sorghum. Asian J. Biotechnol., 2: 14-26.

Omoba, O.S., Omogbemile, A. 2013. Physicochemical Properties of Sorghum Biscuits Enriched with Defatted Soy Flour. British. J. Appl. Sci. Technol., 3(4): 1246-1256.

Oyarekua, M.A., Adeyeye, E.I. 2009. Comparative evaluation of the nutritional quality, functional properties and amino acid profile of co- fermented maize/cowpea and sorghum/cowpea Ogi as infant complementary food. Asian J. Clin. Nutr., 1: 31-39.

Rohrbach, D.D., Kiriwaggulu, J.A.B. 2001. Commercialization prospects for sorghum and peal millet in Tanzania. $\begin{array}{lll}\text { Working paper } & \text { series } & \text { No.7 }\end{array}$ Bulawayo Zimbabwe/Socioeconomic and policy programme ICRISAT.

Sanni, L.O., Adebowale, A.A., Tafa, S.O. 2006. Proximate, functional, pasting and sensory qualities of instant yam flour. A paper presented at the 14th ISTRC symposium, Central Tuber Crops Research Institute, Trivandrum, Kerala State, India.

Sanni, S.A., Adebowale, A.R.A., Olayiwola, I.O., Maziya-Dixon, B. 2008. Chemical composition and pasting properties of iron fortified maize flour. J. Food, Agri. Environ., 6: 172-75.

Stipanuk, M.H. 2006. Protein and amino acid requirements. Pages 419-448 in: Biochemical, Physiological, Molecular Aspects of Human Nutrition. M. H Stipanuk, ed. Saunders Elsevier: St. Louis, MO.

Vatsala, C.N., HaridisRao, P. 1991. Studies on invert syrup for use in biscuits. Food Sci., 28: 149-152.

West, C.E., Repping, F., Temalilwa, C.R. 1988. Handbook on the composition of food commonly eaten in East Africa. Published by Wangnening, The Netherlands.

\section{How to cite this article:}

Mohammed Abdel Rahman Hussain Ahmed, Abdelmoneim Ibrahim Mustafa, Hayat Abdel Rahman hussan and Ahmed Elawad Elfaki. 2016. Proximate Composition, Protein Digestibility, Starch Digestibility, Physical Properties and Sensory Evaluation of Decorticated Sorghum and Maize Biscuits Supplemented with Chickpea Flour. Int.J.Curr.Res.Aca.Rev.4(5): 1-11. doi: http://dx.doi.org/10.20546/ijcrar.2016.405.001 